\title{
Implementing Service Learning: From Nutrition Education into Community Action
}

Lana Zinger, Queensborough Community College, USA

Alicia Sinclair, Queensborough Community College, USA

\begin{abstract}
Service learning integrates academic learning and relevant community service with classroom instruction, focusing on critical, reflective thinking and personal civic responsibility. Through a grant, community college students were provided with grocery store vouchers to purchase unfamiliar, healthy foods. Students were taken on an educational "tour" of a local supermarket and were shown how to grocery shop according to dietary guidelines. Students then engaged in service learning by going out into their communities where they acted as nutrition educators and taught community members skills they initially learned. As a result of this project, students reported success in applying the knowledge and skills learned from one setting to another. By engaging in service learning, students also reported improved nutrition knowledge and overall confidence with the subject matter.
\end{abstract}

Keywords: Service learning, teaching

\section{INTRODUCTION}

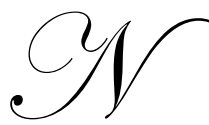

ational studies suggest that students in effective serving learning courses improve academically, increase attendance in class, and develop personal and social responsibility. Definitions of service learning may differ slightly, but the hallmarks of service learning are applied "real" projects or work that provide a beneficial service to organizations and/or individuals outside of the classroom and reinforce course-related skills and content. This project helped college students translate nutrition education into community action.

This program used service learning pedagogy to teach community college students how to:

- $\quad$ Engage in learning through active participation in service experiences.

- $\quad$ Promote learning through active participation in service experiences

- $\quad$ Structure time to reflect by thinking, discussing and/or writing about their service experience

- $\quad$ Use skills and knowledge in real-life situations

- $\quad$ Extend learning beyond the classroom and into the community

- $\quad$ Foster a sense of caring for others

(as adapted from the National and Community Service Act of 1990)

The purposes of this project:

1. To provide students with basic knowledge of how to make health promoting choices when food shopping.

2. To empower students to implement behavioral strategies learned when on their own.

3. To teach students how to teach others what they've learned. 


\section{SERVICE LEARNING RESEARCH}

Review of service learning literature from a health and nutrition education context indicates that service learning pedagogy helps students become better advocates of nutrition and health awareness outside of the classroom.

A study by Litke (2002) on the outcomes of service learning found that both higher an lower performing students clearly believed that the course had an impact on personal growth. Also significant was the students' abilities to apply the knowledge and skills they learned from one setting to another.

Palmer (1997) reported that real learning occurs when the course content and the experiences of the students intersect. Service learning as part of a course provides students with real world experiences that enhance course learning objectives.

In 2002, Moley et al, reported that students who participated in service learning showed expected changes in civic attitudes and an increase in self-rating in regards to their skills for community engagement. They also reported that service learning gave students opportunities to develop social and problem solving skills including communication and conflict resolution.

In 1998, Kezar wrote that, "in the broadest sense, service learning is a form of active, experiential learning that utilizes service in order to ground the learning process".

\section{STUDENT RESPONSE TO SERVICE LEARNING}

Service learning in our College consisted of recruiting students from our introductory health courses. Student participation was voluntary and students who did participate were given $\$ 25.00$ grocery store vouchers. Students met with faculty members at a local supermarket. Students were then divided into small groups and assigned a faculty member who conducted the supermarket tour. The supermarket tour entailed:

The tour started with a short introduction by the faculty with information about healthy nutrition and the role of fat, especially saturated fat, in the diet. Next, the group walked along the supermarket aisles and the focus was on a number of product groups (e.g. milk products, butter and oils, etc). The faculty discussed the fat content and the kind of fat [saturated or (poly) unsaturated] in different products. The groups then walked through the aisles and learned how to practice reading nutrition labels. They then went to those parts of the store where foods without labels - such as produce, fish and fresh meats - are sold. Here we discussed the nutritional value of a type of food. The groups then went to the deli counter and the bakery. During the tour, faculty provided a general store layout for shoppers. They pointed out the freshest foods in the market — the produce, fish and fresh meat — are usually along the perimeter of the store, while processed foods dominate the aisles.

During the tour several educational methods were used by the faculty. Information was given using posters, handouts and product samples. To stimulate active participation, questions were asked by the faculty, participants were given small tasks, games were played and participants were offered products to taste. Then, participants were encouraged to read the nutrition products. On average, the tour took 90 minutes. At the end of the tour the participants received written information to take home, i.e. pamphlets about fat intake, recipes and healthy nutrition in general.

The main purpose of the tour is to help participants to better understand the nutrition information on products in order to learn about the fat content of their food choices and to show them possible low-fat alternatives.

As part of the nutritional experience students learned:

- $\quad$ How to read food labels

- How to spot and discover nutritional power packed food 
- $\quad$ How to get the most for your money

- $\quad$ Nutritional content of food

- $\quad$ Healthy, quick snacks

- $\quad$ Meal ideas

- $\quad$ How to choose seasonally, locally produced food

- $\quad$ And how basic, healthy ingredients can be transformed into a delicious healthy meal the whole family will love.

Students were required to select a minimum of three people such as another student, a family member, friend or any other community member and conduct a similar supermarket tour without supervision from a faculty member. Their experiences were then recorded in a "reflection journal". Students were required to submit these journals at the end of the semester in place of taking a final exam. The journal content was more than a mere log of events. Instead, students related their experiences and reflections as they related to course content and objectives.

\section{WHAT MAKES SERVICE LEARNING WORK?} the process.

Several things are critical for service learning success and should be addressed by practitioners throughout

\section{Community Needs}

Service-learning addresses genuine needs that are important to the community being served.

\section{Tailor To Course Objectives}

In order to differentiate service-learning from regular community service work, educators must carefully tie projects to specific course objectives.

\section{Student Response}

Reflection activities, such as a reflection journal, can be used to assess where students are in the learning process, provide opportunities for them to voice concerns and share feelings, and evaluate the project.

\section{Partnerships}

Service-learning builds partnerships between students and their community. Partnerships can be limited to those being served or extended to include businesses, community-based organizations, social service agencies, and other groups that share the project's goals.

\section{RECOMMENDATIONS}

The following recommendations proved useful when implementing this service learning project:

1. Students' grades are based on the demonstration of learning and meeting course objectives.

2. The syllabus should include the rationale for incorporating community service into the course as well as specific student expectations.

3. Build and foster relationships with the broader community

4. Develop assignments that enable students to demonstrate what they learned from the community experience. 


\section{CONCLUSION}

Through the process of setting up and facilitating this service learning project, QCC faculty members and students have an increasing presence within the community. For example, students reported that recipients of this service learning project had higher interest in personal health and nutrition. It was also reported that recipients were interested in pursuing possible health and nutrition career pathways by signing up for continuing education classes at QCC.

In the classroom, faculty members reported improved camaraderie among students and among faculty members involved in this project. Faculty noticed student attentiveness while in class was improved because students were more engaged as witnessed by higher quality questions, increased participation and overall greater interest in the subject matter. This project could potentially contribute to healthier schools and communities and better prepared students who possess the skills necessary to teach nutrition and health.

"Service-Learning goes beyond charity or volunteerism. It encourages those involved in service ministry to ask the hard questions and search for real solutions. Service-Learning programs explicitly include features which foster participants' learning about the larger social issues behind the human needs to which they are responding." Jane C Kendall, Combining Service \& Learning

"Service-learning makes academic content come alive as students apply their knowledge and skills to reallife situations. Students become more engaged in their studies and see that they can make a difference. Taking an active role in addressing community needs fosters responsible citizenship and contributes to character development." Jack O'Connell, California State Superintendent of Public Instruction

\section{AUTHOR INFORMATION}

Dr. Lana Zinger is a certified health education specialist (CHES) as well as a registered dietician (R.D.). She is currently an assistant professor of health education at Queensborough Community College of The City University of New York where she teaches a variety of health related courses. She's received funding for the implementation of service learning projects in her classes and has spoken about service learning at different conferences around the country.

Dr. Alicia Sinclair (CHES) is an assistant professor of health education and nutrition at Queensborough Community College of The City University of New York where she teaches a variety of health and nutrition related courses. She's received funding for the implementation of service learning projects in her classes and has spoken about service learning at different conferences around the country.

Both authors are graduates of New York University and Columbia University.

\section{REFERENCES}

1. Combining Service \& Learning: A Resource Book for Community and Public Service. (Raleigh: National Society for Internships and Experiential Education, 1990), p. 20.

2. The International Partnership for Service Learning and Leadership. IPSL Declaration of Principles. 2006

3. The National and Community Service Act of 1990: http://www.nationalservice.org

4. The National Service Learning Clearinghouse: $\mathrm{http} / / / \mathrm{www}$. servicelearning.org/welcome.

5. Making and impact on out-of-school time: A guide for corporation for national service programs engaged in after school, summer, and weekend activities for young people. Wellesley, MA: National Institutue on Out-of-School Time at Wellesley College Center for Research on Women. 2000.

6. Kezar, A.J. (1998). Exploring new avenues for leading community colleges: the paradox of participatory models. Community College Review. 25(4). 75-87.

7. Litke, RA. Do all students "get it"?: Comparing students' reflections to course performance. Mich J Community Service Learning. 2002;8(2):27-34. 
8. Moley,B.E., MeFarland,M., Miron, D., et al. Changes in college students' attitudes and intentions for civic involvement as a function of service learning experiences. Mich J Community Service Learning. 2002;9(1):44-51.

9. Palmer,P. The courage to teach: Exploring the inner landscape of a teacher's life. San Francisco: JosseyBass; 1997.

\section{NOTES}




\section{NOTES}

